\title{
AN ICE-SHELF MORAINE, GEORGE VI SOUND, ANTARCTICA
}

\author{
by \\ D. E. Sugden and C. M. Clapperton \\ (Department of Geography, University of Aberdeen, St. Mary's, High Street, \\ Old Aberdeen AB9 2UF, Scotland)
}

\section{ABSTRACT}

The morphology, sediments, and processes associated with the construction of a moraine along the western margin of the ice shelf in George VI Sound, Antarctica, are discussed. The moraine occurs as a double ridge where the ice sheet grounds against promontories on Alexander Island and is approximately horizontal over a distance of $120 \mathrm{~km}$. It consists of exotic rock debris carried into the ice shelf by Antarctic Peninsula glaciers and local rock debris derived from the grounding 1 ine on Alexander Island. As the coast steepens, so the proportion of exotic rocks increases. The transport of basal material from the peninsula implies that there can be little bottom melting beneath this part of the ice shelf. The moraine is modified by streams and marginal lakes which periodically drain into and through the ice shelf. Tidal lakes are impounded against the ice shelf in shallower embayments and consist of fresh water overlying sea-water. A conceptual model of the moraine is developed and may help to explain some features of puzzling horizontal moraines found in formerly glaciated areas.

\section{INTROOUCTION}

Relict ice-shelf moraines are thought to exist in many formerly glaciated areas. England and others (1978) describe how in northern Canada the lateral moraines of former sea-terminating outlet glaciers can be traced into $2 \mathrm{~km}-1$ ong, shell-bearing horizontal moraines. In eastern and northern Greenland there are several puzzling horizontal moraines. Examples include a $40 \mathrm{~km}$ ridge on the northern shore of Scoresby Sund (Funder, personal communication), a $4 \mathrm{~km}$ ridge on Wollaston Foreland (where erratic content indicates an onshore movement), a $2 \mathrm{~km}$ ridge on the coast of south-east Peary Land, and a series of horizontal features extending for $30 \mathrm{~km}$ near the southern entrance of D $\phi \mathrm{ve}$ Bugt (Hjort, personal communication). The horizontal nature of these ridges points tentatively to the role of an ice shelf at least as one factor in their development.

observations from presently forming iceshelf moraines are sparse and give little guide to the morphology or main processes involved. Debenham (1920, 1965), Gow and others (1965), and Swithinbank (1970) discussed the origin of rock debris on the ablating surface of the McMurdo Ice Shelf in Antarctica, and Lyons and Miekle (1973) make brief mention of debris-laden ice ridges where an ice shelf grounds against Ward
Hunt Is]and in northern Canada. The purpose of this paper is to discuss the morphology and processes involved in the construction of a horizontal moraine along the margin of the ice shelf in George VI Sound (Fig. 1). It is hoped that the model which is evolved will help to explain some of the features of relict ice-shelf moraines in other parts of the world.

George VI Sound is a block-faulted trench over $20 \mathrm{~km}$ wide and $500 \mathrm{~km}$ long and separates the mainly plutonic, tectonic block of the Antarctic Peninsula from the sedimentary rocks of middle and southern Alexander Island (Adie 1964, Bell 1975). The ice shelf in the sound is nourished mainly by ice flowing from the Antarctic Peninsula, which is $c .200 \mathrm{~km}$ across in this vicinity with mountains rising to $3000 \mathrm{~m}$. It has been shown that the ice shelf flows 20 to $50 \mathrm{~km}$ across the sound to Alexander Island

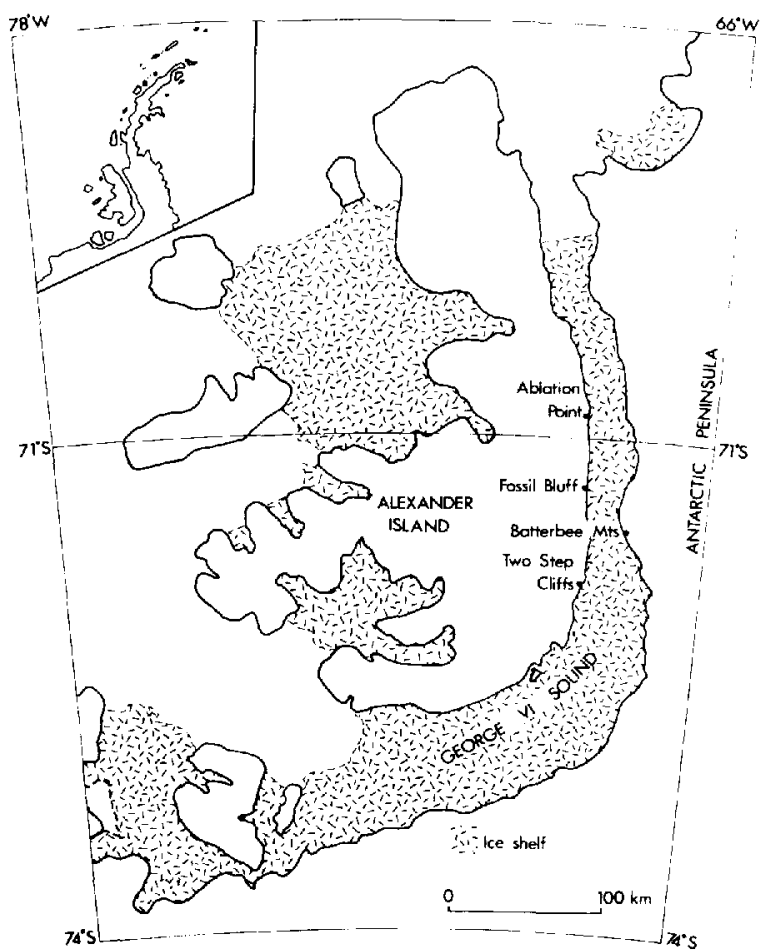

Fig.1. Location map showing the ice shelf in George VI Sound. 
but that there is also a slight northward movement along most of the sound (Swithinbank 1968 , Pearson and Rose, in press). These main flow lines are picked out by surface lake patterns on Landsat imagery (Fig. 2). In the Ablation Point/ Two Step Cliffs area, the ice shelf varies in thickness from around 400 to $500 \mathrm{~m}$ near the Antarctic Peninsula to around 100 to $300 \mathrm{~m}$ along the coast of Alexander Island. Temperatures at a depth of $10 \mathrm{~m}$ vary from $-8 \mathrm{C}^{\circ}$ in the Ablation Point area to $-100 \mathrm{C}$ in the Two Step Cliffs area (Martin and Peel 1978). Where the ice shelf grounds against Alexander Island or meets local glaciers there is a complex zone of pressure ridges with an amplitude of from 10 to

$15 \mathrm{~m}$ (Fig. 3). At two places near Ablation Point the grounded ice shelf blocks the mouths of valleys and impounds tidal lakes (Heywood 1977). The lake in Ablation Valley is $5 \times 2 \mathrm{~km}$ in size and up to $70 \mathrm{~m}$ deep while that in Moutonnee valley is $1.5 \times 1 \mathrm{~km}$ in size and up to 50 m deep.

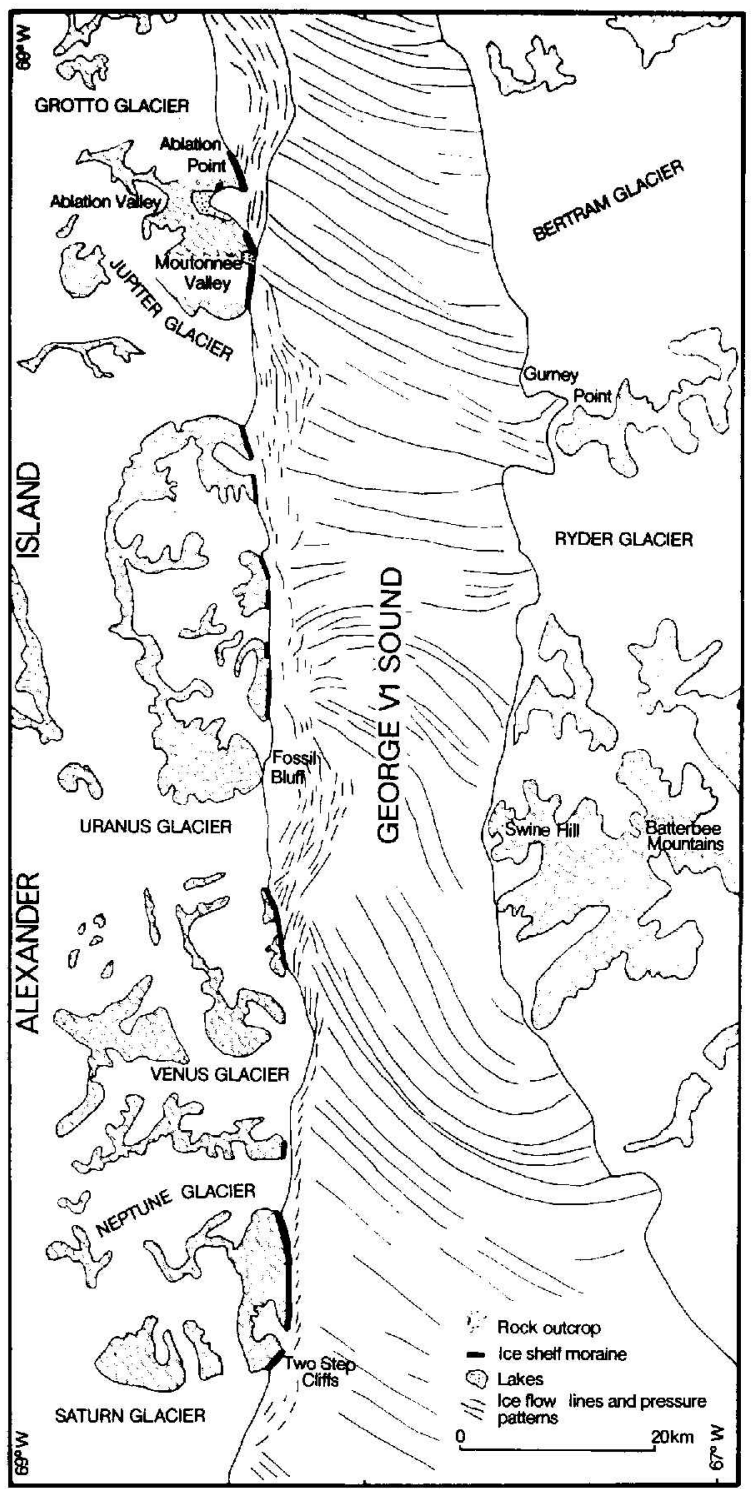

Fig.2. The location of the ice-shelf moraine in relation to flow lines on the ice shelf. Flow lines are inferred from surface lake patterns visible on Landsat images.

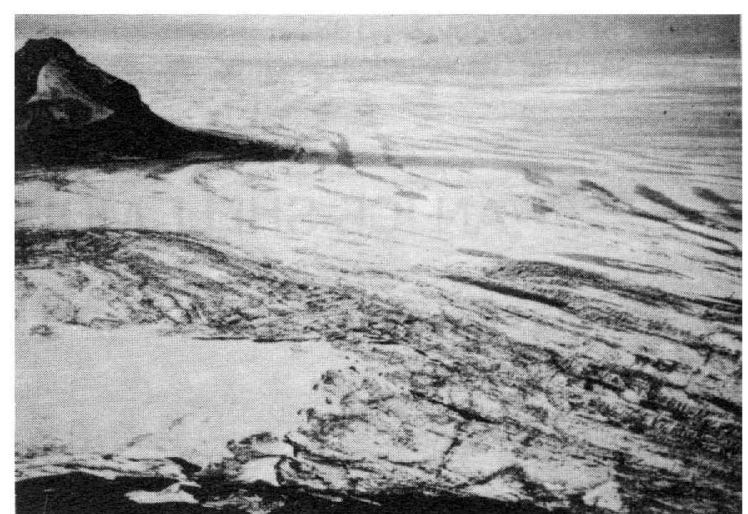

Fig.3. The ice shelf in the vicinity of Ablation Point (left background). The regular lake pattern is on the floating ice shelf and the smooth surface in the left foreground is the ice-covered Ablation Lake. The complex area of pressure ridges in between marks the zone of grounding. Photo taken in late January 1979.

\section{MORAINE MORPHOLOGY}

The moraine is approximately horizontal over a distance of $120 \mathrm{~km}$ along the eastern promontories of Alexander Island between latitudes $710^{\circ} 15^{\prime} \mathrm{S}$ and $72^{\circ} 00^{\prime} \mathrm{S}$. It also extends partially across the mouth of the Moutonnee valley embayment and penetrates some distance into Ablation Valley (Fig. 2). The moraine has two main morphological components (Fig.4). Adjacent to the active ice margin one component consists of an unstable zone of icecored debris, which in places forms sharpcrested ridges 2 to $10 \mathrm{~m}$ high and elsewhere forms broad $(c .200 \mathrm{~m})$ areas of gently undulating topography where the ice is overlain by melt-out and flow tills (Fig.5). The ridges are characterized by active slumping where slope angles exceed $35^{\circ}$ and in many places the ice core is within 100 to $300 \mathrm{~mm}$ of the surface. A single ridge is the most common landform but three or more ridges and the broader bands of melt-out debris with complex micro-morphology seem more typical of embayments and areas where the ice shelf is aground on a more gently sloping land surface. The second component occurs on the landward side of the first and is a subdued moraine ridge up to $5 \mathrm{~m}$ high with slopes generally less than $10^{\circ}$. In most places the
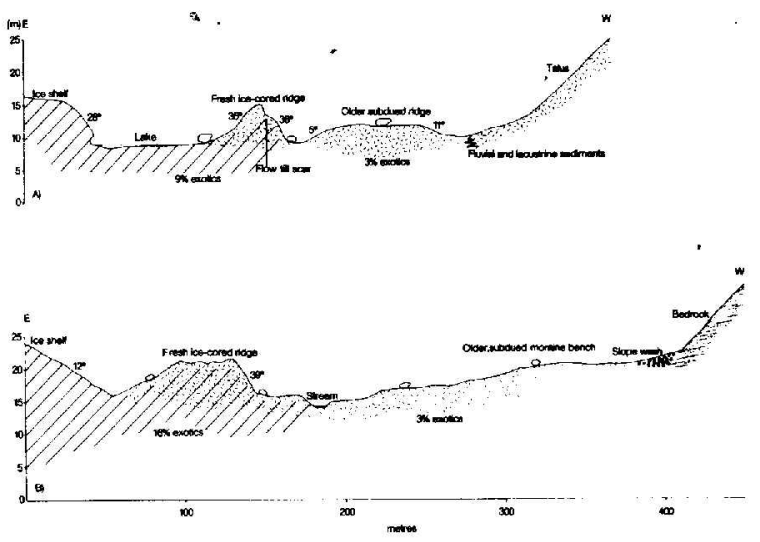

Fig.4. Two transects across the moraines (a) $2 \mathrm{~km}$ north of Ablation Point and (b) just south of Ablation Valley. 


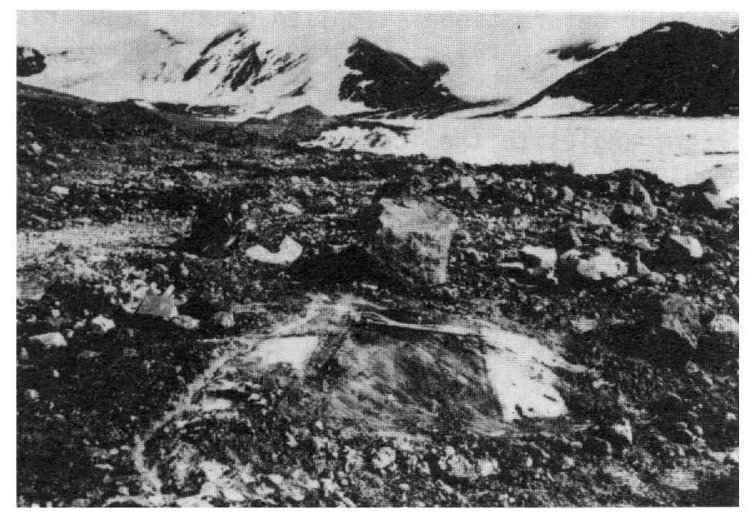

Fig.5. Surface melt-out till typical of the zone adjacent to the ice-cored ridge. The debris has been removed from part of the area to expose the underlying ice.

moraine occurs as a single ridge but some sections of the deposit have bench-like morphology, typically 30 to $40 \mathrm{~m}$ wide. At Ablation and Moutonnée lakes the subdued moraine extends farther into the embayments than the sharp-crested moraine, but in some places the subdued moraine is missing altogether, even although the sharp-crested one is present; this situation seems only to occur at promontories where the slopes of Alexander Island descend steeply to the ice shelf, as, for example, just south of Moutonnée Lake. Both moraine components are pocked by kettle holes: ice is usually visible on the sides of kettle holes in the sharp-crested moraine, but was not seen in association with the subdued moraine. The crests of both ridges are everywhere lower than the surface of the pressure ridges in the adjacent grounded ice shelf.

\section{MORAINE COMPOSITION}

The material comprising the moraines varies in nature from loose accumulations of coarse angular debris to compacted till composed of well-abraded and striated clasts in a clayey matrix. Boulders 1 to $3 \mathrm{~m}$ in size litter the surface and al though many are angular, others bear the smooth abraded and striated surfaces commonly associated with a subglacial environment. Mechanical analysis of the fine fraction revealed a matrix typical of such basal debris (Fig.6). Of particular interest are the lithologies present. Although the majority of clasts are sedimentary rocks, especially the shale and volcaniclastics typical of Alexander Is 1 and, igneous rocks of a type not found locally on the island are also present. White, grey, red, and pink granites, gneiss, and granodiorite are typical. Randomly located counts of boulders over $500 \mathrm{~mm}$ in size in areas measuring $20 \times 20 \mathrm{~m}$ revealed that these exotic boulders commonly comprise 4 to $70 \%$ of the total. At one locality on the moraine blocking Moutonnée Valley such exotics were the only boulders present. The percentages mentioned above are also typical of smaller clast sizes. Granite and gneiss pebbles occur in the conglomerates of Alexander Island but are clearly distinguished by their greater degree of chemical weathering (confirmed by examination in thin section), the water-rounded cobble surface, conspicuous iron staining, and their smaller size. Counts were initially restricted to boulders greater than $500 \mathrm{~mm}$ in size in order to

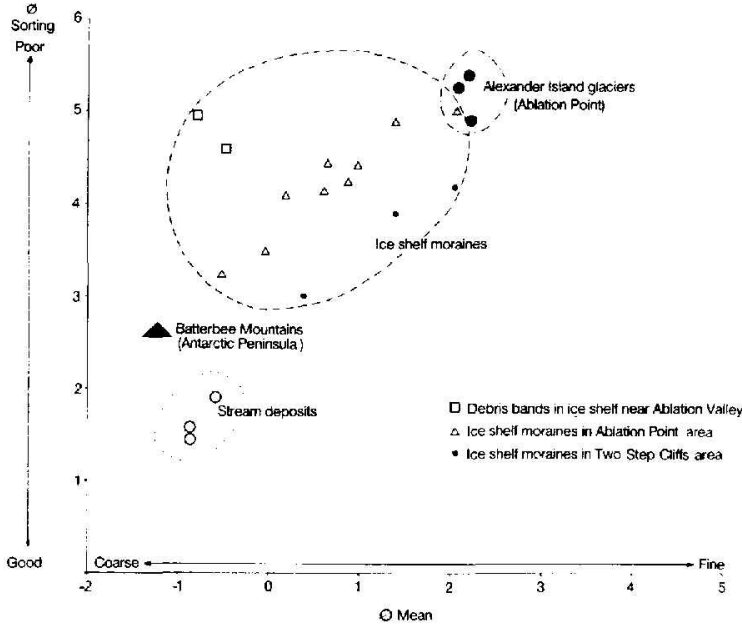

Fig.6. A plot of mean size against sorting of the sediment matrix $(<2 \mathrm{~mm}$ size) of samples from the ice-shelf moraines and debris bands. For comparison, plots are also shown of local Alexander Island outlet-glacier tills, a plateau till from the Antarctic Peninsula, and stream deposits from the morainic complex.

minimize the possibility of confusion with locally derived conglomerate.

Three lines of evidence suggest that the exotic rocks have been derived from the Antarctic Peninsula: (a) Granites and gneiss of the type found are known to occur as bedrock on the peninsula but not in middle and southern Alexander Island (British Antarctic Survey Map Series 500G). This is confirmed by the absence of granite and gneiss erratics in moraines of neighbouring Alexander Island glaciers and is in contrast with their occurrence in the ice-shelf moraines and their dominance in peninsula tills; (b) Although the geology beneath the glaciers of the peninsula is not known in sufficient detail to permit the close matching of exotics with known bedrock outcrops, one match was established. Samples of granodiorite and gneiss found in the ice-shelf moraine near Ablation Point are identical to samples of granodiorite and gneiss bedrock outcropping on Gurney Point on the southern flank of the Bertram Glacier, which lies further up a flow line (Fig. 2): (c) Tests of the magnetic characteristics of the fine matrix in the ice-cored till just north of the glacier at Two Step Cliffs show the till to be more closely related to granite and gneiss bedrock than to the local sedimentary rocks of Alexander Island (F. 01dfield, personal communication).

Interesting though the exotics may be, it is important to stress that on the whole the iceshelf moraines consist of local Alexander Island rocks. This is reflected not only in the stone lithology counts but also in magnetic measurements on the fine matrix near Ablation Point, which suggest that here the ice-shelf matrix is derived from shale. Mixing of local and exotic debris is also consistent with the mechanical analysis data shown in Figure 6 . This shows most ice-shelf tills lie intermediately between the fine-grained, poorly sorted tills of Alexander Island and the coarser, better sorted (mainly due to the lack of fine material) tills of the Batterbee Mountains. The percentages of clay in the tills also support this conclusion. The mean percentage of clay-sized material in a 
sample of Alexander Island basal tills was found to be $9.75 \%$ (standard deviation $\sigma=3.7$ ) and that in the Batterbee Mountain tills $0.79 \%(\sigma=0.2)$. The ice-shelf moraines have an intermediate mean value of $5.3 \%(\sigma=2.9)$ and range from $11.46 \%$ to $0.48 \%$. Significantly the lowest values in the ice-sheif moraine occur in those areas where the exotic material is most abundant. For example, the lowest value of a $11,0.48 \%$ in the ice-cored moraine just north of Two step Cliffs, coincides with the sample thought by magnetic measurements to be the most closely related to granite and gneiss bedrock. The next lowest value (3.6\%) coincides with the site between Jupiter Glacier and Moutonnee Lake where stone counts revealed $70 \%$ of the large boulders were exotic.

There are interesting spatial variations in the proportion of local and exotic debris. At a broad scale the exotic content of the moraines is highest where the ice shelf grounds close to the coast, for example just north of Two Step Cliffs and in the Moutonnee Valley area. The proportion of local rocks increases when the ice shelf grounds well offshore, for example, off Ablation Valley, and also where it meets larger Alexander Island glaciers. North of the junctions of Saturn and Jupiter glaciers local rock debris dominates the $\mathrm{jce}$-shelf moraines and the exotics appear only 1 or $2 \mathrm{~km}$ to the north. At a small scale there is extreme variability of the proportions of exatic and local rocks within the space of a few metres. It was common to find a 1 to $2 \mathrm{~m}$ wide linear zone of 1 ocal rocks parallel to the moraine crest immediately adjacent to a similar narrow zone of exotic rocks. Some material in the ice-shelf moraines is derived from below sea-level in the sound. This is illustrated by the presence of barnacle shells, Bathy Zasma corrolziforme (Hoeke), found in the landward subdued moraine at Two Step Cliffs. The present bathymetric range of this barnacle in open sea is 200 to over $1000 \mathrm{~m}$ (Newman and Ross 1971). Though unlikely to be growing beneath the ice shelf today (Sugden and Clapperton 1980), the shells have presumably been derived from beneath sea-level after the growth of the ice shelf. No other evidence of marine derived material was found, however, despite close scrutiny for foraminifera and analysis of $\mathrm{CaCO}_{3}$ content (inconclusive results averaging $0.63 \%$ ).

\section{MAIN PROCESSES OCCURRING ALONG THE ICE-SHELF} MARGIN

\section{Glaciological processes}

\section{The onshore flow of ice is}

complemented by upward and slight lateral components of movement. Upward movement implied by the presence of a surface till cover on the ice shelf associated with surface melting. But perhaps the clearest evidence for upward ice movement was seen in the case of upl ifted stream sediments. One $\mathrm{km}$ south of Moutonnée Valley is a stream which flows mainly on land but formerly flowed onto the ice shelf in a meander. A meander was subsequently abandoned and sediments associated with it have since been elevated $8 \mathrm{~m}$ in relation to the river bed on the 7 and. The northward component of movement is implied not only in the pattern of the pressure ridges and the flow lines of the ice shelf, but was derionstrated at a point immediately north of Moutonnée val ley. Here a bedrock outcrop of a distinctive lava protrudes into the zone of active moraine. Large blocks of lava derived from the outcrop occur in the ridge to the north but not to the south.

Ice movement at the ice margin includes both regular deformation and thrusting.
Regular deformation is implied by the regularity of foliation parallel to the ice margin which dips into the ice shelf at angles of 30 to $70^{\circ}$. The wall of a fresh melt-water channel cut at right angles to the ice margin $3 \mathrm{~km}$ south of Moutonnée Valley showed layers of white bubbly ice varying in thickness from 100 to $600 \mathrm{~mm}$ alternating with bands of blue ice varying from 20 to $300 \mathrm{~mm}$ in thickness. They were sub-parallel and dipped at an angle of around $60^{\circ}$. Differential ablation of the surface of the $i c e$ shelf revealed these foliation structures along most of the ice margin. Thrusting was observed in an abandoned melt-water tunnel $2 \mathrm{~km}$ south of Moutonnée Valley. The tunnel ran into the ice shelf at right angles to the margin for a distance of at least $50 \mathrm{~m}$. Its diameter decreased from $20 \mathrm{~m}$ at the tunnel entrance to $5 \mathrm{~m}$ in the interior. The presence of the previous winter's snow cover in the tunnel entrance showed that it had not been used by melt water for at least 8 months. Some 20 to $30 \mathrm{~m}$ from the entrance the floor and sides of the tunnel had been dislocated in relation to the entrance by three abrupt $2 \mathrm{~m}$-high steps. There was also a slight lateral displacement of $1 \mathrm{~m}$ towards the north. The freshness of these steps demonstrated that they formed at some time after the tunnel was abandoned by melt water. No debris was found in association with these faults, but ice-cored moraine occurred in the vicinity of the tunnel entrance.

Evidence that marginal ice contains rock debris was seen in many sections along the iceshelf margin. One such example just south of Ablation Valley is shown in Figure 7. The exposure measures $1.5 \times 1.0 \mathrm{~m}$ and is the plan view of an approximately horizontal ice surface overlain by ice-cored debris. The 50 to $750 \mathrm{~mm}$ cover of melt-out debris was removed from the ice before measurement and sampling (Fig.5). The main feature was the presence of a band of transparent ice containing debris sandwiched between debris-free, white, foljated ice. All bands dipped towards the ice shelf at angles of 66 to $85^{\circ}$. The transparent ice contained debris bands with clasts orientated parallel to the debris bands. Analysis showed the matrix to comprise a mean clay-sized fraction of $5.7 \%$ $(\sigma=1.9)$ and silt-sized fraction of $15.4 \%$ $(\sigma=0.06)$. These values are closely comparable

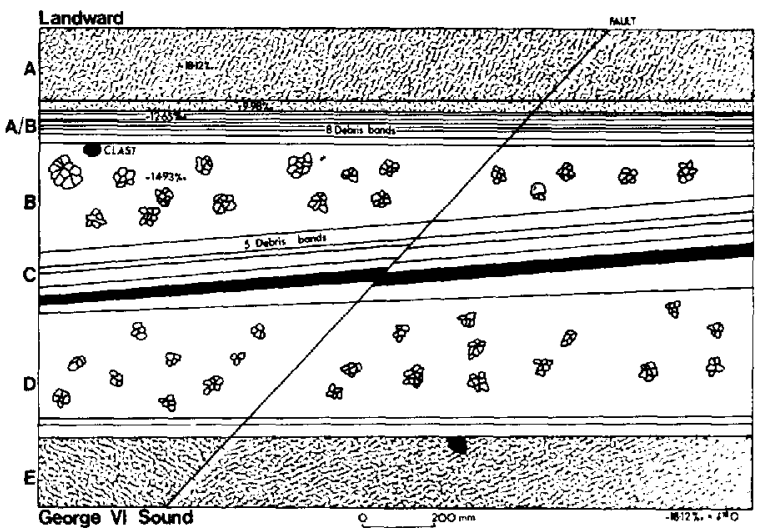

Fig. 7. Plan view of part of horizontal surface of the ice shelf underlying till, just south of Ablation Valley. Site of cleared ice is shown in Figure 5 . A, E : white, foliated, bubbly, debris-free ice; $A / B$ : transparent, debris-poor ice with few bubbles; $C$ : debris bands in transparent ice; $D$ : blue, debrispoor ice with few bubbles. 
to the ice-shelf moraines, al though the latter are finer overall (Fig.6). Clasts in the debris bands consisted of local shales $(48 \%)$ and volcaniclastics $(52 \%)$, though exotic granites and gneisses occurred in the surface melt-out debris. $20 \%$ of the clasts were abraded. All clasts seen in the ice were incorporated within the thicker debris bands or, in the case of the thinner bands, were immediately adjacent to them. Two samples of 30 to $60 \mathrm{~mm}$-thick debris bands were found to comprise $45 \%$ and $58 \%$ rock debris when measured by weight. Most debris bands were thinner than this and, for example, eight debris bands occurred within a distance of $90 \mathrm{~mm}$. The transparent ice between the debris bands consisted of ice crystals 5 to $30 \mathrm{~mm}$ in diameter with a mean of $15 \mathrm{~mm}$. The crystals contained some air bubbles and also traces of rock flour, amounting to $0.05 \%$ of the total by weight. No very large boulders were seen in the patch of ice examined, but one measuring $850 \times 530 \times 470 \mathrm{~mm}$ was lying on the ice surface immediately adjacent to the exposure (Fig.5).

The re'sults of oxygen isotope measurements on the ice from various bands is shown in Figure 7 . The white bubbly ice had a value $\delta^{18} 0=-18.12 \%$ while the transparent ice and debris bands had $\delta 180$ values between $-14.93^{\circ} / \infty$ and $-9.98 \%$. The more debris there was in the ice, the less negative was the value. For perspective, three $\$ 180$ measurements of ice in a small local glacier snout near Ablation Point yielded values of between $-14.11 \%$ and $-15.41 \%$. Typically, pure sea-water would have values close to zero or slightly positive (Stuiver and others 1976).

There seem to be three main mechanisms by which rock debris can be incorporated into the ice shelf: (1) transport into the ice shelf by inflowing glaciers; (2) incorporation at the point of grounding by bottom freezing; and (3) incorporation at the point of grounding by ice sliding.

The first mechanism would explain the debris in the ice shelf as being derived from rock debris contained in both Antarctic Peninsula and Alexander Island glaciers which enter the ice shelf. The clearest evidence is concerned with the northern lateral moraines of Saturn and Jupiter glaciers which merge into the ice-shelf moraine. For 1 or $2 \mathrm{~km}$ north of the confluence, the iceshelf moraine consists wholly of this local debris before becoming progressively mixed with other material. The presence of the exotic granites and gneisses suggests that this same mechanism also operates with regard to Antarctic Peninsula glaciers. The presence of striations on some exotic clasts, their abraded shapes, and the grain-size characteristics of the fine fraction suggest that at least some of the material is basal in origin. In places where the exatics comprise most of the deposit then it is reasonable to suggest that the debris is directly related to the inflowing glaciers.

The incorporation of material by bottom freezing from an intermittently grounded ice shelf has been suggested both for the Ward Hunt (Lyons and Miekle 1973) and the McMurdo (Gow and others 1965) ice shelves. In the case of George VI Ice Shelf there is evidence to support such an origin for much of the material. The presence and character of the debris bands and the existence of fine debris in the transparent ice is typical of bottom freezing (Weertman 1961). The freezing-on could occur at the point of grounding and this would explain the dominance of local rocks in most of the moraine. Whereas the $\delta^{18} 0$ determinations rule out the possibility of pure sea-water freezing onto the bottom, they suggest that the refreezing involves a net addition of fresh or brackish water. The value of $-9.98 \%$ is particularly high for the Ablation Point latitude and is consistent with alteration by refreezing of isotopically heavier water (Peel, personal communication). Fresh water was found to underlie part of the McMurdo Ice Shelf (Gow and others 1965), and it occurs to a depth of $55 \mathrm{~m}$ in Ablation Lake which is less than $1 \mathrm{~km}$ distant from the ice exposure depicted in Figure 7 (Heywood 1977). It is notable that the brackish water freezing onto the bottom of the Ward Hunt Ice Shelf had similar values in the range of $-13.22 \%$ to $-17.47 \%$ (Lyons and others 1971).

The third mechanism of debris incorporation by ice sliding at the point of grounding is likely to be a contributory process of entrainment. In this case, sliding ice is able to transport fragments of bedrock, especially large boulders, by plastic flow of ice around them. When the tractive force exerted by the ice overcomes frictional resistance then the rock clast will move. Some such process would help to explain the incorporation of large boulders of Tocal origin which are not carried into the ice shelf by Alexander Island glaciers.

Once entrained in the ice shelf, processes of upward ice flow are necessary to transpart basally-derived debris to the ice surface. One such process is upward flow in response to surface ablation and has long been recognized (Debenham 1920, Swithinbank and others 1961). In the case of George VI Ice Shelf, the zone of strong upward flow may be confined to the edge where locally increased ablation is related to the proximity of the ice-free slopes of Alexander Island. Thrusting along upward curving shear planes is a second process which may be important in transporting debrisbearing ice to the ice-shelf surface. The dislocation of the melt-water tunnel is good evidence that thrusting occurs.

Melt-water processes

The influence of melt-water processes on the morphology and sediments of the ice-shelf moraine is profound. Along stretches of steep coast temporary lakes occur at intervals of 1 to $2 \mathrm{~km}$. Generally the lakes occupy basins between the ice margin and the land and may be over $100 \mathrm{~m}$ across. Where there is a landward embayment larger lakes may build up. Periodically the lakes drain into the ice shelf via ice tunnels. A fine example was seen draining away on 10-11 January 1979. The lake was in an embayment south of Moutonnee Valley and at $1400 \mathrm{~h}$ on 10 January measured $1.4 \times 0.2 \mathrm{~km}$ and was up to $10 \mathrm{~m}$ deep. Then, 24 hours later, approximately $1.12 \mathrm{~m} \times 10^{6} \mathrm{~m}^{3}$ of water had drained through a sump $25 \mathrm{~m}$ wide and $10 \mathrm{~m}$ high at the intake. Afterwards water was flowing from the ice-shelf surface into the sump via a moulin. Former lake beaches occur both higher and lower than the one vacated in 1979, implying that the lake may reach different dimensions in different years before draining each summer. old sumps were seen in association with other lake sites and it seems clear that there may be a regular cycle by which the marginal lakes build up before draining suddenly through the ice.

The lakes seem typical of those discharging englacially whereby, after an initial seepage is established, outflow accelerates rapidly due to the widening of the tunnel by melting (Röthlisberger 1972). The main point of interest is that, unlike many other instances of englacial drainage, here the lakes are draining through ice with a $10 \mathrm{~m}$ temperature 
of around $-9^{\circ} \mathrm{C}$ (Martin and Peel 1978). In this situation fracturing associated with both thrusting and tidal movements may make available passages for the initial seepage of melt water. The lakes are important in influencing the morphology of the moraine in that the lake sumps occupy low points which become the facus of stream drainage. Thus a walk along the depression between the morainic ridges or between the moraine and the land involves passing through a series of local stream basins 1 to $2 \mathrm{~km}$ across, each focused on a lake sump. The lakes also modify the sediments in and on the moraine. The ice-cored ridge in the vicinity of the lake that was observed to drain away was almost wholly comprised of beach shingle. Finer lacustrine silts may also be incorporated in flow till sequences on the ice-cored moraine and occur in depressions between the ridges. Tidal lake processes

Characteristics of the tidal lakes in Ablation and Moutonnée valleys are well described by Heywood (1977). In both lakes a fresh-water layer overlies sea-water. In Ablation Lake the fresh-water layer is $55 \mathrm{~m}$ thick while in Moutonnee Lake it is around $33 \mathrm{~m}$ thick. In Ablation Lake salinity measurements show that the tidal fluctuations involve the inflow and outflow of sea-water beneath the ice shelf. In the case of Moutonnée Lake the exchange is an intermediate brackish layer which corresponds to the depth of the sill on which the ice shelf grounds. Both lakes are covered by ice throughout the year which is 4.0 to $4.5 \mathrm{~m}$ thick in winter and 2.6 to $3.0 \mathrm{~m}$ thick in summer (Fig. 3). Remarkably, Heywood found both a marine fauna, including the fish Trematomus bernachiz, in the bottom of Ablation Lake and a sparse fresh-water fauna in the upper layers, notably a fresh-water calanoid. Streams flow into both lakes and are constructing fans and deltas. Presumably the sediments in the upper part of the del ta will be accumulating in fresh-water conditions, while in the deeper portions of the lake sedimentation is taking place in marine conditions complete with a marine fauna. Thus a variety of other landforms and sediments associated with the presence of such tidal lakes become part of the ice-shelf moraine complex.

\section{AGE RELATIONSHIPS}

The only clue to the age of the ice-shelf moraine is that the barnacles in the subdued ridge at Two Step Cliffs are 6000 to $6500{ }^{14} \mathrm{Ca}$, an age which agrees with the amino acid analyses (Sugden and Clapperton 1980). The position of the shells shows that both moraines must be younger than 6000 to $6500{ }^{14} \mathrm{C}$ a.

\section{A MODEL OF THE ICE-SHELF MORAINE}

Figure 8 is an attempt to portray the processes associated with the formation of the ice-shelf moraine in George VI Sound. Glaciers discharging from the Antarctic Peninsula flow across the sound as an ice shelf and transport basal debris from the peninsula. This implies there can be little bottom melting beneath the ice shelf. The ice shelf grounds against Alexander Island and varying quantities of local Alexander Island debris are incorporated by freezing and glacier sliding. Surface ablation and thrusting allow basal debris to move upwards to the ice surface where it forms an ice-cored moraine.

As the coast steepens the grounding line nears the coast, so the proportion of exotic debris in the moraine increases and the resulting ridge complex narrows. Conversely, if the coast is shallow, the more extensive will be the zone of grounding, and so the higher will be the proportion of local rock debris, and the broader will be the belt of moraine topography. Melt-water processes are highly important in modifying the morphology and sediments in the moraine. The most important effect is to create lake basins which act as local base levels for streams flowing parallel to the moraine and which periodically drain through the ice shelf. The net result is an approximately horizontal moraine occurring on coastal forelands over a distance of $120 \mathrm{~km}$ but with a locally undulating long profile. The sediments in the moraine may comprise local or exotic till or any combination of the two, fluvio-glacial and lacustrine sediments, and in places, a marine fauna.

Before this model can be applied elsewhere $i t$ is wise to stress the major constraints influencing the formation of the ice-shelf moraine in

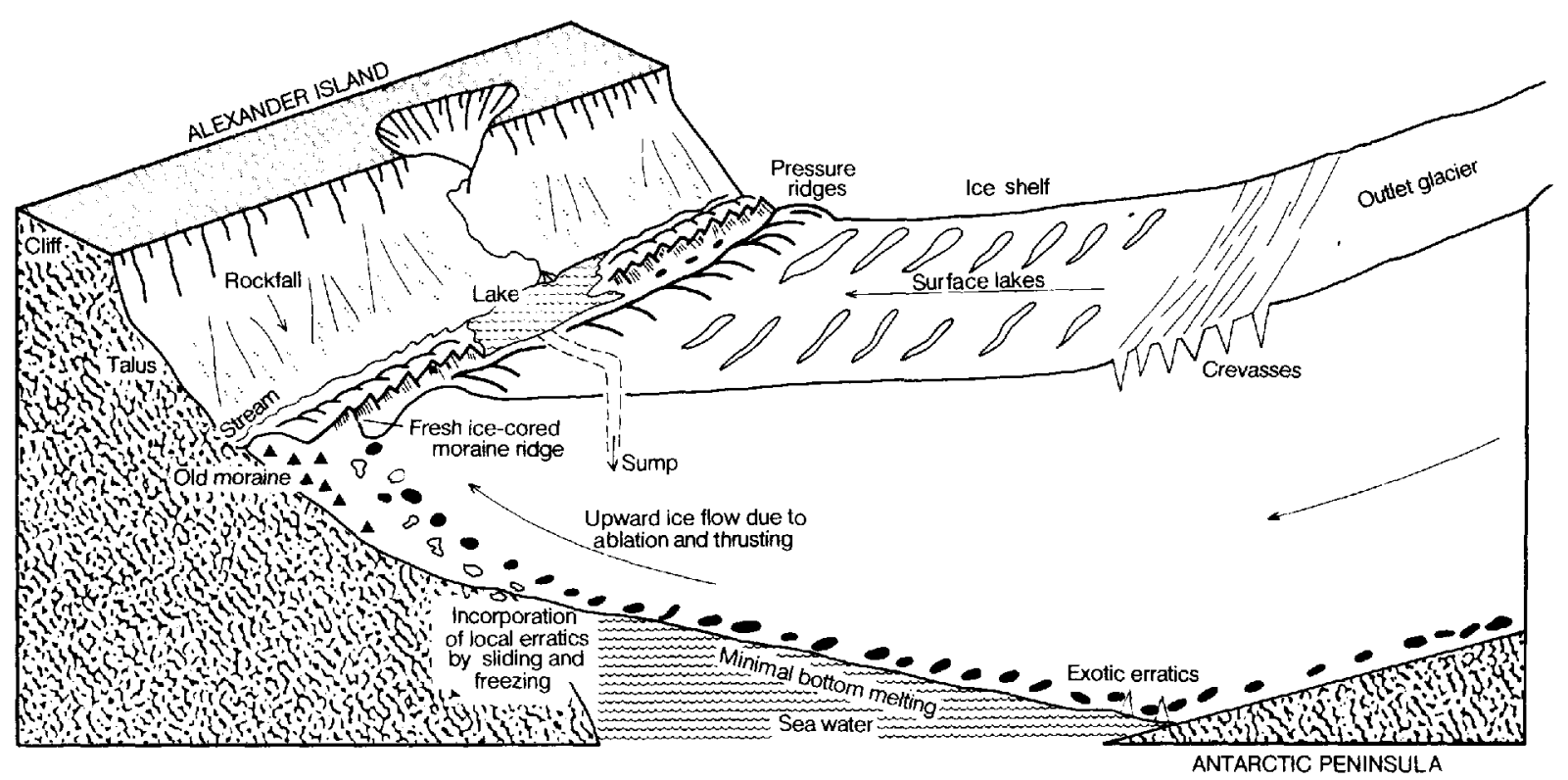

Fig.8. Conceptual model of processes forming the ice-shelf moraine in George VI Sound. 
George VI Sound. These constraints are both glaciological and topographic. The main glaciological constraint is that the mass balance of the ice shelf must be sufficient to cause the ice shelf to cross the sound, but little more. Only in such a situation can surface ablation and compressive thrusting bring rock debris to the surface. If the mass balance were markedly higher and surface ablation unimportant, then basal material would remain within the ice. This situation applies at either end of George VI Sound where the mass balance is higher (Wager 1972) and no marginal moraine occurs. The mass balance of the ice shelf also influences flow lines. If it was higher, then ice flow would tend to be towards the north or south along the sound rather than across it. This change would modify 1 ithological patterns and presumably reduce the exotic content of the moraine.

Finally the mass balance influences the altitude of the moraine. Where the ice shelf is thinner the moraine will be lower and vice versa. This factor probably contributes to deviations from the truehorizontal in the'case of the existing moraine. A stronger component of flow along the sound would create a slight overall gradient to the moraine.

The topography of the grounding zone is another fundamentally important variable.

Intuitively one can argue that the coast on which the moraine forms needs to be sufficiently steep to allow the floating ice shelf to come close inshore before grounding and yet it needs to be sufficiently gentle to allow the moraine to accumulate. The block-faulted eastern margin of Alexander Island may just represent the optimum topographic situation. It is tempting to speculate on the situation where, as is common, the coast is gentler. Perhaps the tidal lakes are analogies of this situation. Here the ice shelf first touches bottom well offshore and, as in the case of Ablation Lake, pushes onshore in a series of pressure ridges for about $1 \mathrm{~km}$ before terminating in a tidal lake in water 50 to $70 \mathrm{~m}$ deep. In such situations one can envisage submerged moraines forming at the edge of the ice shelf. Depending on local conditions, this moraine could consist of varying proportions of glacial, marine, lacustrine, or stream deposits, and be mixed with a marine or fresh-water fauna, or both at the same time.

\section{ACKNOWLEDGEMENTS}

We thank the Natural Environment

Research Council and the British Antarctic Survey for support. We are very grateful for help provided by Professor Dansgaard, Dave England, Dr Hjort, Mrs Kennedy, Or Newman, Professor 01dfield, Dr Shaw, and Dr Swithinbank.

\section{REFERENCES}

Adie R J 1964 Geological history. In Priestley R E, Adie R J, Robin G de $Q$ (eds) Antarctic research. A review of British scientific achievement in Antaretica. London, Butterworths: 118-162

Bell CM 1975 Structural geology of parts of Alexander Island. British Antaretic Survey Buzzetin 41-42: 43-58

Debenham $F \quad 1920$ A new mode of transportation by ice: the raised marine muds of south Victoria Land (Antarctica). Quarterly Joumial of the Geological Society of London 75(2): 51-76

Debenham $F 1965$ The genesis of the McMurdo Ice Shelf. Antarctica. Joumal of Glaciology $5(42): 829-832$
England J, Bradley R S, Miller G H 1978 Former ice shelves in the Canadian high Arctic. Joumal of Glaciology 20(83): 393-404

Gow A J, Weeks W F, Hendrickson G, Row 7 and $R$ 1965 New light on the mode of uplift of the fish and fossiliferous moraines of the McMurdo Ice Shelf, Antarctica. Joumaz of Glaciology 5(42): 813-828

Heywood R B 1977 A limnological survey of the Ablation Point area, Alexander Island, Antarctica. Phizosophical Transactions of the Royal Society of London B 279(963): $39-54$

Lyons J B, Miekle J E 1973 Holocene history of a portion of northernmost Ellesmere Island. Aretic $26(4): 314-323$

Lyons J B, Savin S M, Tamburi A J 1971 Basement ice, Ward Hunt Ice Shelf, Ellesmere Island, Canada. Joumal of Glaciology 10(58): 93-100

Martin P J, Peel D A 1978 The spatial distribution of $10 \mathrm{~m}$ temperatures in the Antarctic Peninsula. Journal of Glaciology 20(83): $311-317$

Newman WA, Ross A 1971 Antaretic cirpipedia. Monographic aceount based on specimens collected chiefly under the united States Antaretic Research Program, 1962-1965. Washington, DC, American Geophysical Union (Antarctic Research Series 14)

Pearson M R, Rose I $H$ In press. Dynamics of George VI Ice Shelf. British Antarctic Survey Buzletin

Röthlisberger H 1972 Water pressure in intraand subglacial channels. Joumal of GLaciology 11(62): 177-203

Stuiver M, Yang I C, Denton G H 1976 Permafrost oxygen isotope ratios and chronology of three cores from Antarctica. Nature 261(5561): 547-550

Sugden DE, Clapperton C M 1980 West Antarctic ice sheet fluctuations in the Antarctic Peninsula area. Nature 286(5771): 378-381

Swithinbank C W M 1968 Radio echo sounding of Antarctic glaciers from light aircraft. International Association of Scientific Hydrology Publication 79 (General Assembly at Berm): $405-414$

Swithinbank C W M 1970 Ice movement in the McMurdo Sound area of Antarctica. Intemationat Association of Scientific Hydrology Publication 86 (ISAGE) : 472-487

Swithinbank C W M, Darby D G, Wohlschlag DE 1961 Faunal remains on an ice shelf. Science 133(3455): 764-766

Wager A C 1972 Flooding of the ice shelf in George VI Sound. British Antaretic Sumey Bulzetin 28: $71-74$

Weertman J 1961 Mechanism for the formation of inner moraines found near the edge of cold ice caps and ice sheets. Joumal of Glaciology 3(30): 965-978 